\title{
綿用カード機におけるシリンダ ワイヤの研究
}

\author{
（第 1 報）ンリンダ ワイヤの歯角度
}

$\begin{array}{clll}\text { 名古屋工業技郝試験所 } & \text { 木 } & \text { 村 } & \text { 弘 (会員) } \\ \text { " } & \text { 長 谷川 } & \text { 進 ( " })\end{array}$

\section{The Cylinder Wire of Carding Machine for Cotton. \\ Part 1: On the Acting Angle of the Metallic Wire Equipped with the Cylinder.}

\author{
Hiroshi Kimura and Susumu Hasegawa, \\ Government Industrial Research Institute, Nagoya, Kitaku, Nagoya.
}

\begin{abstract}
The relationship was studied between the quality of the sliver and the acting angle of the metallic wire using by a carding machine equipped with a doffer wound by wire fillet card clothing.

The acting angle of the doffer on this experiment was $40^{\circ}$. The acting angle of the metallic wire was changed from $75^{\circ}$ to $60^{\circ}$ and its point density was $356 /(25.4 \mathrm{~mm})^{2}$. Also, the angle of the flat was changed from $75^{\circ}$ to $95^{\circ}$ to study the corelation between the angle of the cylinder and the flat.

The results were as follows:

1) By lowering the angle of the metallic wire from $75^{\circ}$ to $65^{\circ}$, the amount of the nep in the sliver was decreased. However, at $60^{\circ}$ in the acting angle of the metallic wire, the neps were much more decreased than at $65^{\circ}$ under the angle of the flat of $95^{\circ}$.

2) The neps in the sliver was decreased in propotion with the increase of the flat angle.

3) The trush in the sliver was unchanged with the change of the angle of th metallic wire. But, it increased by increasing the flat angle.

4) The mean length of the fiber in the sliver was not affected by the angle of the metallic wire.

The same results summarized above will be obtained even if the fiber transfer ratio of the doffer wound by the metallic wire is same.

(Received September 21, 1979)

\section{摘 要}

目 的 針角度 $40^{\circ}$ の針布ドッファを付けたカード機で、ンリンダワイヤの歯角度とスライバの品質との関係を調へた。 ンリ ンダワイヤの歯角度は $75^{\circ}$ から $60^{\circ}$ まで変化させたが, その歯密度は $356 /(25.4 \mathrm{~mm})^{2}$ とした. またンリン夕゙ワイヤの歯角度 とフラットの針角度との関係を調へるため, フラットの針角度を $75^{\circ}$ から $95^{\circ}$ まで変化させた。

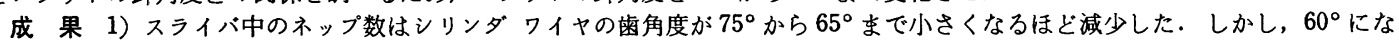
ると $65^{\circ}$ に比べフラットの針角度が $95^{\circ}$ ではネップ数はさらに減少したが, フラットの針角度が $75^{\circ}$ では増加した。

2) スライバ中のネップ数はフラットの針角度が大きくなるほど減少した.

3）スライバ中のトラッンュはンリンダワイヤの歯角度を変化させても変らなかった。しかし、フラットの針角度が大きくなる ほど増加した.

4) スライバの平均綸維長はンリンダワイヤの歯角度を変化させても変らなかった.

以上の結果はメタリックワイヤを巻いたドッファを使用してもドッファの纎維移行率が同じであれば同一の結果が得られるは ずである. （昭和54年 9 月 21 日受理）
\end{abstract}

\section{1. まえがき}

綿紡用カード機において，シリンダに巻かれるメタリ
ックワイヤの雪角度は従来 $75^{\circ} \sim 77^{\circ}$ が一般に使用され ている. シリンダワイヤの歯角度を検討した報告とし ては $72^{\circ} 〜 85^{\circ}$ の範囲について 実験した野薮等の報告 ${ }^{11}$ 
がある.しかし，70より小さい齒角度については実験

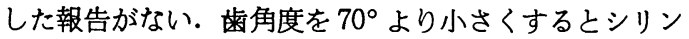
ダに瀻維が巻付きやすくなり，機械が正常に運転できな くなる恐れがあって $70^{\circ}$ 以下の歯角度は実用性のない角 度と考えられていたのではなからうか。

そこで

1） シリンダ ワイヤの 齒角度を $70^{\circ}$ より小さくする ことによって生ずるシリンダの緘維の巻付きは筆者等が 考案した 瀻維移行率の大きい 針角度 $40^{\circ}$ の 針布ドッフ

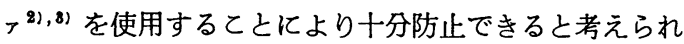
るとと.

2） シリンダワイヤの 齒角度を小さくすることによ り繊維を把持する力が大きくなり開瀻作用が良好となっ て高品質のスライバが生産できるのではないかと考えら れるとと等, の理由より筆者等は上記の針布ドッフっを 使ってシリンダ ワイヤの歯角度を $75^{\circ}$ から $60^{\circ}$ まで変 化させた実験を行った．シリンダ ワイヤの歯角度を変 化させるとフラットとの相互作用とドッファへの緘維移 送作用とが同時に変化する．そのため実験はドッファの 回転数を一定にした実験 (A)（フラットとの相互作用と ドッファへの繊維移送作用とが相乗して变化する実験） と,ドッファへの緘維移送作用を一定にしてシリンダと フラットとの相互作用のみを誦べる実験(B)の 2 通りを 行った。 またシリンダ ワイヤの歯角度とフラットの針 角度との 相互作用を調へるため，フラットの針角度を $75^{\circ}$ から $95^{\circ}$ まで变化させた実験を実験 $(\mathrm{B})$ で併せて 行 った.

\section{2. 実験装置および実験方法}

図 1 に実験に 使用した シリンダ の形状およびシリン ダ ワイヤの巻付け位置を示す. シリンダ幅は $1020 \mathrm{~mm}$

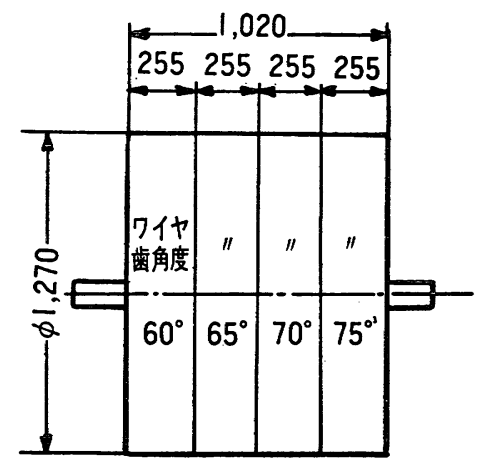

図 1 ンリンダの形状㧤よ゙ワイヤの巻付け位置

の通常の編紡用のものであり, 軸方向に $255 \mathrm{~mm}$ ずつに 4 分割して歯角度 $60^{\circ}, 65^{\circ}, 70^{\circ}, 75^{\circ}$ のワイヤを巻付け た. 実験したワイヤの諸元を表 1 亿示す.なおワイヤの
表 1 メタリック ワイヤと針布の諸元

\begin{tabular}{|c|c|c|c|c|c|}
\hline & ワイヤの & $\begin{array}{l}\text { 歯角度 } \\
\text { 針角度 } \\
\left({ }^{\circ}\right)\end{array}$ & $\begin{array}{l}\text { 番の深さ } \\
\text { 腰上高さ } \\
\text { (mm) }\end{array}$ & $\begin{array}{l}\text { 䔎高 } \\
\text { 針高 } \\
(\mathrm{mm})\end{array}$ & $\begin{array}{l}\text { 宷 密 度 } \\
\text { 針 密 度 } \\
\left(1 /(25.4 \mathrm{~mm})^{2}\right)\end{array}$ \\
\hline $\begin{array}{l}\text { シリン } \\
\text { ダ }\end{array}$ & $\begin{array}{l}\text { メタリッ } \\
\text { ク イヤ } \\
\end{array}$ & 60 & 0.8 & 3 & 356 \\
\hline II & II & 65 & II & II & II \\
\hline II & 11 & 70 & 11 & II & "I \\
\hline "I & II & 75 & II & II & II \\
\hline $\begin{array}{l}\text { フラッ } \\
\text { ト }\end{array}$ & 針 布 & 75 & 5 & 10 & 550 \\
\hline II & II & 85 & II & 11 & II \\
\hline II & II & 95 & II & II & $1 /$ \\
\hline $\begin{array}{l}\text { ドッフ } \\
\text { フ }\end{array}$ & 針 布 & 40 & 3 & 17 & 300 \\
\hline
\end{tabular}

歯密度は瀻維の巻付き防止を考慮して 通常の 600/(25.4 $\mathrm{mm})^{2}$ より大幅に小さい $356 /(25.4 \mathrm{~mm})^{2}$ の屯のを使用 した.

また実験に使用したドッファは直㺯 $161 \mathrm{~mm}$ の小形の あのであり，針角度 $40^{\circ}$ の針布が巻付けられた針布ドッフ フである．針布の諸元を表 1 亿示す．とのドッファ2),31 は次のような特徴を持っている.

1）針布の針角度が $40^{\circ}$ と小さいため（通常の針角度 は $\left.65^{\circ} \sim 70^{\circ}\right)$ 瀻維移行率が大きく，シリンダに瀻維が巻 付きにくい.

2）針角度が小さい針布であるため重いスライバが紡 出できる.

3）ドッファ回転数を一定にしてスライバ生産量を增 加させ，スライバ重量を大きくしても瀻維移行率はほと んど低下しない。

一方，シリンダ ワイヤの歯角度とフラットの針角度 との 相互作用を調べるため, フラットは針角度 $75^{\circ}$, $85^{\circ}, 95^{\circ}$ の 3 種類のものを準備した。 そのフラット針 布の諸元を表 1 亿示す.

次にカード機の運転条件を表 2 亿示す. 実験に使用し たラップは 30s 用綿で, 1 実験当り $250 \mathrm{~mm}$ 幅のあのを $360 \mathrm{~g}$ 供給した。 またスライバ生産量は $20.8 \mathrm{~kg} / \mathrm{hr}$ (乙 の生産量はラップをカード機全幅に供給した生産量に換 算した）としたが，乙れは通常生産量 $5 \mathrm{~kg} / \mathrm{hr}$ の 4 倍 である.てのように生産量を大きくしたのは

1）実験したラップの幅は通常ラップの $1 / 4$ である. そのためスライバ重量が小さく緇維移行率の測定に誤差 が生じ易くなるので，スライバ生産量を大きくしスライ バ重量の増加をはかった。

2）スライバ中の異物数はスライバ生産量が大きくな るほど増加する. しかし異物数の測定精度は計数増加に よって向上させるととができる. 
表 2 運転条件

\begin{tabular}{|c|c|}
\hline シリンダ回転数(rpm) & 183 \\
\hline テーカイン回転数(rpm) & 465 \\
\hline ドッフォ回転数 $(\mathrm{rpm})$ & $30,15 \sim 30$ \\
\hline フラット速 度 $(\mathrm{mm} / \mathrm{min})$ & 停 止 \\
\hline フラット ゲージ(in) & $8 / 1000 \sim 9 / 1000$ \\
\hline スライバ生産量(kg/hr) & 20.8 \\
\hline 供 給 ラッ プ & 30s 綿 \\
\hline 供給 ラップの幅(mm) & 250 \\
\hline 1 実験のラップ使用量 $(\mathrm{g})$ & 360 \\
\hline
\end{tabular}

注）トッッファは直径 $161 \mathrm{~mm}$ のものを使用した.

等と考えたからである。

カード機の各部の回転数は表 2 に示すようにシリンダ $183 \mathrm{rpm}$, テーカイン $465 \mathrm{rpm}$ であり，てれらはカード 機で促来使用している回転数である. ドッフっの回転数 については $30 \mathrm{rpm}$ で行った実験(A)とシリンダ ワイ ヤの歯角度によって 15３0 r pm に変化させた実験(B) の2通りを行った。

またフラットは前報4)と同じく停止の状態で実験し， フラットゲージは各実験すべて 8/1000〜9/1000 in に 設定した.

\section{3. 真の繊維移行率とドッファ回転数との関係}

從来の繊維移行率 ${ }^{5)}$ は定常状態のカード機において， ラップの供給を急に停止し，それによるスライバ重量の 減衰加ら計算して求めている. 重量減衰するスライバの 繊維はシリンダ上に付着していた繊維ばかりでなく, フ ラットの針布に付着していた繊維のうちシリンダにか き取られて排出されるすのあ含まれている．そのため從 来の繊維移行率はフラットの繊維量の影響を含めたもの である. 一方，本実験のようにシリンダ ワイヤの歯角 度を変化させる場合はシリンダとフラットとの相互作用 ばかりでなく，シリンダからドッファへの繊維移送作用 あ同時に変化するので, ドッフっの回転数を一定にして あシリンダとフラットとの相互作用を純粋に調べるとと はできない. そのためシリンダとフラットとの相互作用 を純粋に調へるにはフラットの影響を受けない繊維移行 率を一定にして実験する必要がある．したがって本実験 では従来の繊維移行率とフラットの影響がない瀻維移行 率とを区別し，以下後者を真の繊維移行率ということに する.

真の繊維移行率はスライバで作ったラップをフラット を取りはずしたカード機に通せば近似的に求めることが
できる．また真の霍維移行率はドッフ，回転数によって 変化する. そのため シリンダ ワイヤの歯角度を変化さ せても各粜角度に対して適当なドッフっ回転数を設定す ると真の繊維移行率を一定にさせるととが可能である.

図2はシリンダワイヤの各角度における真の瀻維 移行率とドッフっ回転数との関係を示したすのである.

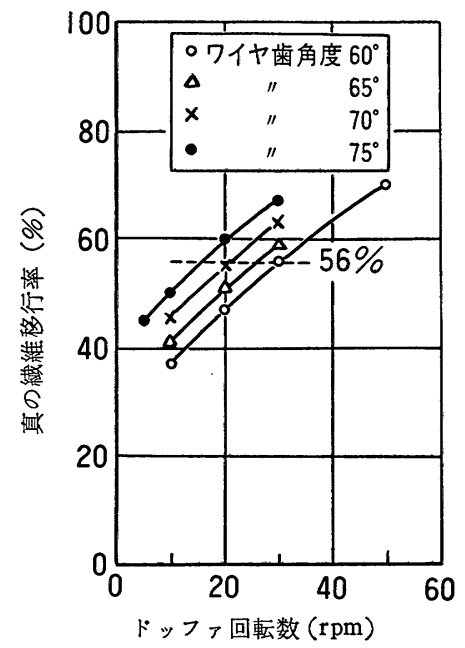

四 2 真の瀻維移行率とドッファ回転数との関係

図からわかるように真の繊維移行率はドッファ回転数が 大きくなるほど増加し, また歯角度が大きくなるほど増 加する.したがって真の霹維移行率を56\%に設定すると 表 3 に示すようにドッフ 、回転数はそれぞれ $30 \mathrm{rpm}$, $25 \mathrm{rpm}, 20 \mathrm{rpm}, 15 \mathrm{rpm}$ となる.

表 3 真の繊維移行率とドッファ回転数の関係

\begin{tabular}{|c|c|c|c|c|}
\hline $\begin{array}{l}\text { シリンダ ワイヤの歯 } \\
\left.\text { 角度( }{ }^{\circ}\right)\end{array}$ & 60 & 65 & 70 & 75 \\
\hline $\begin{array}{l}\text { 真の緎維移行率が56\% } \\
\text { になる、゙ッファ回転数 } \\
\text { (rpm) }\end{array}$ & 30 & 25 & 20 & 15 \\
\hline $\begin{array}{l}\text { ドッファ回転数が } 30 \\
\text { rpmの真の繊維移行率 } \\
(\%)\end{array}$ & 56 & 59 & 63 & 67 \\
\hline
\end{tabular}

一方, ドッファ回転数 $30 \mathrm{rpm}$ の真の繊維移行率は表 3 に示すようにそれぞれ $56 \% ， 59 \% ， 63 \% ， 67 \%$ 変化 する。

\section{4. 測定方法}

4.1 シリンダ活動綿量とフラット活動綿量 定常状態のカード機において，シリンダおよびフラ ットに付着している繊維を活動綿4〉と沈積綿とに分類す る. 活動綿とはシリンダやフラットに付着している瀻維 のうち, ラップの供給を停止した後シリンダやフラット から離れてドッファへ出てくる紻維をいう. また沈積綿 
とはラップの供給停止後もシリンダやフラットの歯や針 の中に沈んだままドッフっへ出ててない䋐維をいう.フ ラットの沈積綿を徒来からよろい綿といっている。 ま たシリンダの沈積綿はシリンダにメタリック ワイヤが 採用されて以来ほとんど無くなった。

カード機の定常状態におけるシリンダ活動綿量 $C_{0}$ と フラット活動綿量 $f$ (前報4) と同じ手法で求めた。すな わち

1) シリンダ部の活動綿総量 $C$ (シリンダ活動綿量 $C_{0}$ とフラット活動綿量 $f$ との和）はシリンダ上にフラット が設置されている通常の状態で求めた緎維移行率 ${ }^{51}$ を次 の式に代入して求める.

$$
C=S / P_{1} N
$$

$\begin{array}{ll}C: \text { 活動綿総量 } & (\mathrm{g}) \\ S: \text { スライバ生産量 } & (\mathrm{g} / \mathrm{min}) \\ P_{1}: \text { 繊維移行率 } & (-) \\ N: \text { シリンダ回転数 } & (\mathrm{rpm})\end{array}$

2) シリンダ活動綿量 $C_{0}$ は各実験で紡出したスライ バを原料として手作りしたラップをシリンダ上にフラッ 卜がまったくない状態で通して求めた真の繊維移行率 $P_{2}$ を上式と同様の式に代入して求める.

3）フラット活動綿量 $f$ は次の式から近似的に求める ととができる。

$$
f=C-C_{0}
$$

\section{2 よろい綿量およびよろい綿中に含まれるトラッ シュ量}

フラットのよろい綿量は 実験終了後個々のフラット について秤量した.

よろい綿中に含まれるトラッシュ量は40本のフラット のうち代表としてテーカイン側から数えた No. 1, No. 2 , No. 3 , No. 4 , No. 5 , No. 7 , No. 10 , No. 16 , No. 24 , No. 33 の10本のフラットのよろい綿を取出 し，それぞれ $100 \mathrm{mg}$ の試料を作成し，手作業によって リントとトラッシュを分離し秤量した.

\section{3 スライバ中の異物個数}

スライバ中の異物は前報4) と同じく, 異物の種類をネ ップ，みかす，はかす，リントかすの 4 つに分類し，異 物の大きさむ直径で $0.5 \mathrm{~mm}$ 間隔に分類した. 测定は目 で計数し, 各スライバとも $200 \mathrm{mg}$ の試料を 5 回ずつ行 った.

\section{4 スライバの瀻維長}

繊維長分布図記録機(ステープルオグラフ)によって各 スライバとむ10個の ステープル ダイヤグラムを作成し た.それより本数平均繊維長, 重量平均繊維長, Clegg の方法 ${ }^{61}$ による有効絒維長等を求め, また繊維長別重量 累積割合も求めた.

\section{5. 実験結果および考察}

\section{1 瀻維移行率之活動綿量}

図 3(a) (ドッフ>回転数 $30 \mathrm{rpm}$ の場合), 図 3(b) （真の繊維移行率56\%の場合）に緘維移行率を示す. 図

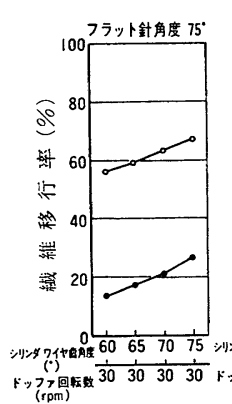

図 3(a) 繊維移行率

(ドッファ回転数 $30 \mathrm{rpm}$ )

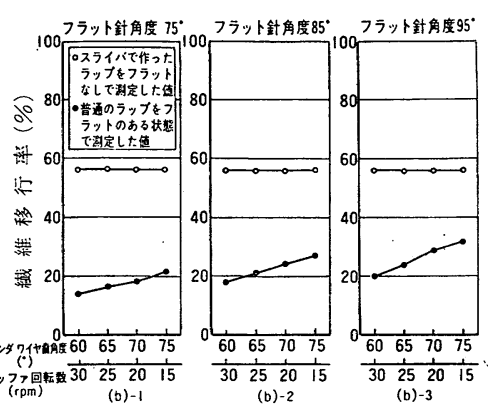

図 3(b) 織維移行率 （真の緎維移行率56\%)

3(a)の縅維移行率はフラットがある場合, フラットが ない場合とあにシリンダワイヤの歯角度が $75^{\circ}$ より小 さくなるほど減少する．フラットがない場合の繊維移行 率はフラットがないためフラット針布の表面に付着する 織維がまったくなく, フラットのある場合の值より相当 大きい。またフラットのない場合の瀻維移行率はシリン ダからドッファへの真の㵶維移行率を示しておりドッ ファの回転数が一定であってあシリンダ ワイヤの歯角 度が恋化すれば影響を受けることを示している。

図 3 (b)-1 のフラットがある場合の繊維移行率は図 3 (a)のそれより歯角度 $60^{\circ}$ を除き小さい．乙机真の 繊維移行率を $56 \%$ と一定にしたためである．またフラッ

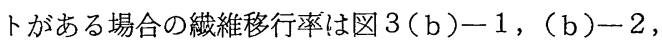
(b) - 3 上むに シリンダ ワイヤの歯角度が $75^{\circ}$ より小 さくなるほど減少する．また緘維移行率はフラットの針 角度が大きくなるほど大きくなる。

図 4 (a) (ドッファ回転数 $30 \mathrm{rpm}$ の場合), 図 4(b)

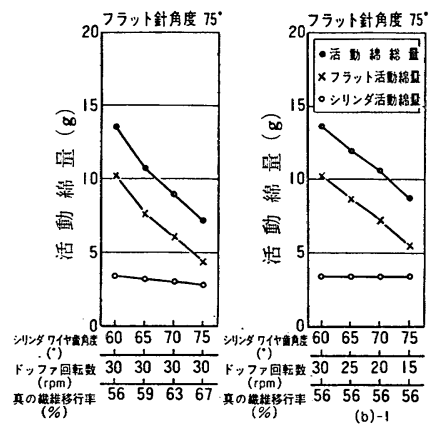

図 4（a）活動綿量 (ドッファ回転数 $30 \mathrm{rpm}$ )

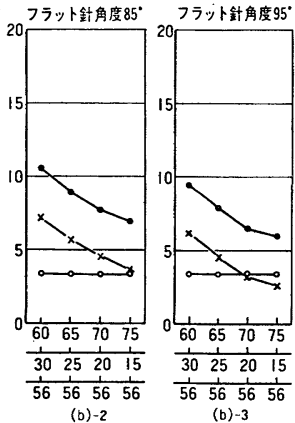

図 4 (b) 活動綿量 （真の緎維移行率 $56 \%$ ) 
真の繊維移行率56\%の場合)に活動綿量を示す.図(4a) の活動綿総量，シリンダ活動綿量およびフラット活動綿 量はとあに シリンダ ワイヤの歯角度が $75^{\circ}$ より小さく なるほど增加する，乙の場合，シリンダ活動綿量は值す 小さく，また歯角度の減少に対しわずかしか增加しな い. しかしフラット活動綿量はシリンダ活動綿量より大 きく，しかす歯角度の減少につれて著しく增加する．乙 れはフラットの針布がシリンダのメタリックワイヤよ り緘維を付着しやすいために生じたすのと考えられる.

図 4(b)-1 のシリンダ活動綿量はシリンダ ワイヤ の歯角度を变化させてあ一定であるが，活動綿総量とつ ラット活動綿量は歯角度が $75^{\circ}$ より小さくなるほど著し く增加する．乙の傾向は図 4 (b) - 2，(b) -3 とむ同 じである.しかしフラット活動綿量と活動綿総量はフラ ットの針角度が大きくなるほど減少する。

\section{2 よろい綿}

A. 個々のフラットにたい積したよろい綿量

図 5 (a) (フラット針角度 $75^{\circ}$ の場合), 図 5 (b)(フ ラット針角度 $95^{\circ}$ の場合）に停止しだ 40 本のフラット

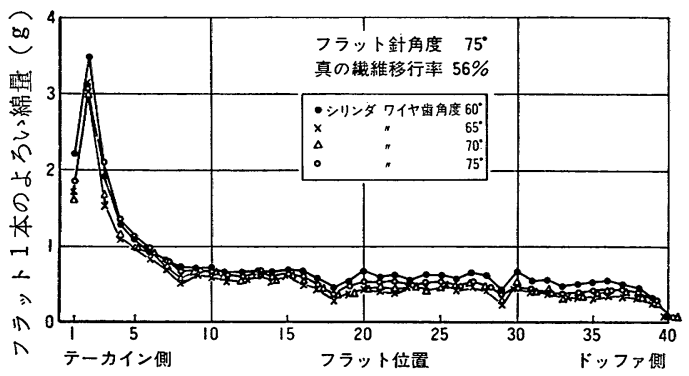

因 5 (a) フラット1本のよろい綿量 (フラット針角度 $75^{\circ}$ )

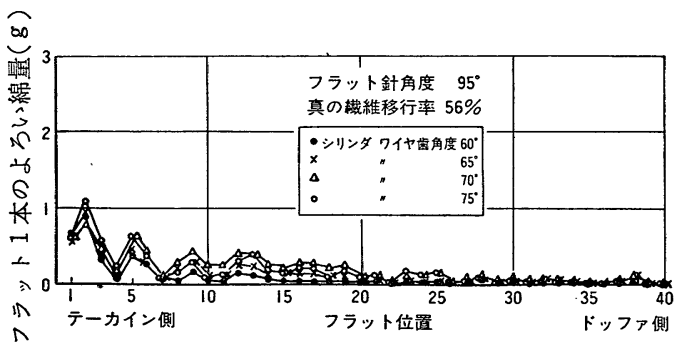

因 5 (b) フラット1本のよろい綿量 $\left(\right.$ フラット針角度 $95^{\circ}$ )

にたい積したよろい綿量を示す. 実験では $250 \mathrm{~mm}$ 幅 のラップ (シリンダ幅の $1 / 4$ ) を使用したので よろい 綿はフラット幅の $1 / 4$ しか たい積しない。しかし図 4 (a), 図 4(b)のフラット活動綿量はシリンダの全幅で 表示したのでそれと比較するためよろい綿量すフラッ トの全幅にたい積した状態に換算して表示した. 図 5 (a), 図 5(b)とむによろい綿のフラット位置に対す るたい積傾向はシリンダ ワイヤの歯角度を変化させて
あ変らない。しかし よろい綿量はフラットの針角度が 大きくなると著しく少なくなる。

B. 累積よろい綿量

図 6 (a) (フラット針角度 $75^{\circ}$ の場合), 図 6 (b)(フ ラット針角度 $95^{\circ}$ の場合）に累積よろい綿量を示す．殏

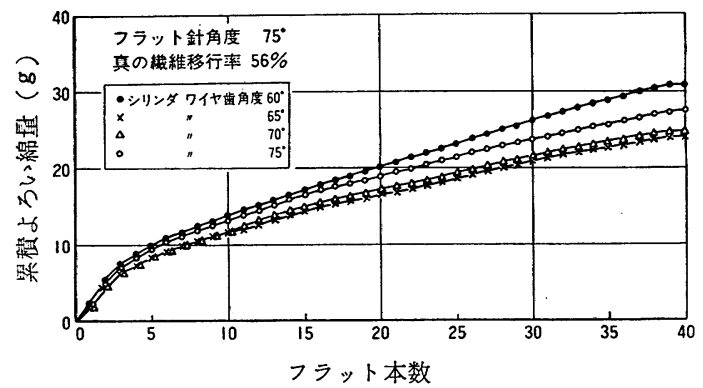

図 6(a) 累積よろい綿量（フラット針角度 $75^{\circ}$ )

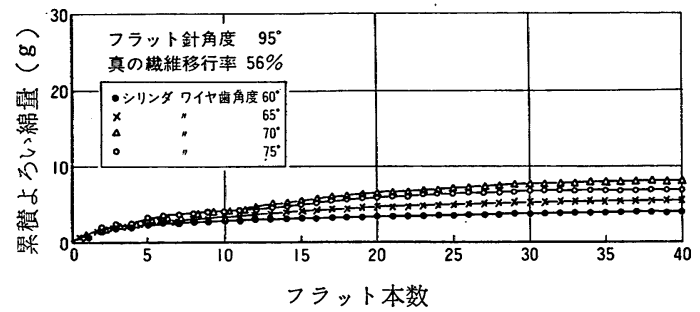

因 6(b) 累積よろい綿量 (フラット針角度 $\left.95^{\circ}\right)$

6 (a)の累積よろい綿量はシリンダ ワイヤの歯角度が $75^{\circ}$ から $65^{\circ}$ まで小さくなるほど減少するが， $60^{\circ}$ で著 しく增加する．また図 6 (b)の累積よろい綿量は歯角度 $70^{\circ}$ でやや多いととを除けば歯角度が小さくなるほど減 少する.

C. 40本のフラットにたいし積したよろい綿全量

図7 (a).(ドッファ回転数 $30 \mathrm{rpm}$ の揚合), 図7 (b) (真の緘維移行率56\%の場合) に40本のフラットにたい 積したよろい綿全量とよろい綿中化含まれるトラッシ 二量とを示す. 図 7 (a)のよろい綿全量はシリンダ ワ
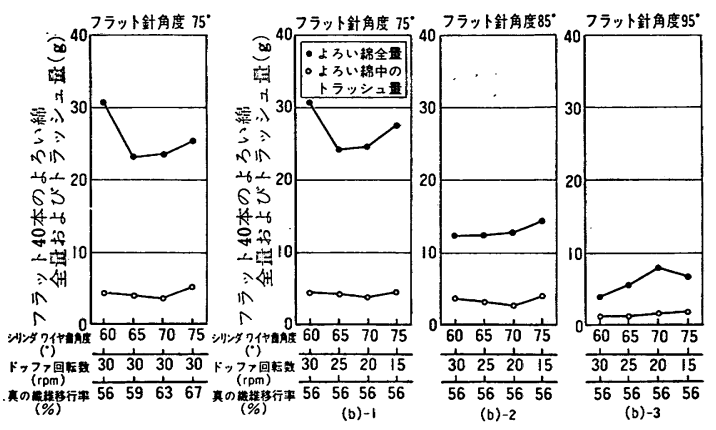

図 7 (a) よろい綿全量 (ドッファ回転数 $30 \mathrm{rpm}$ )

図 7(b) よろい綿全量 (真の繊維移行率 $56 \%$ ) 
イヤの歯角度が $75^{\circ}$ から $65^{\circ}$ まで小さくなるほど減少す るが， $60^{\circ}$ で著しく増加する．一方，よろい綿中のトラ ッシュ量は歯角度 $75^{\circ}$ でやや多いがその他の歯角度では ほとんど変らない。

図7 (b)-1 のよろい綿全量はシリンダ ワイヤの歯 角度を变化させてあ図 7 (a) と同じ傾向を示す. しかし 歯角度 $75^{\circ}$ から $65^{\circ}$ までの よろい綿全量は図 7 (a) の それよりわずかに多い，図7(b)-2，(b)-3のよ ろい綿全量はシリンダ ワイヤの歯角度が小さくなるほ ど減少する．したがってよろい綿全量が異常に多くな るのはフラット針角度 $75^{\circ}$ ，シリンダ ワイヤ歯角度 $60^{\circ}$ の場合のみである．またよろい綿全量はフラットの針 角度が大きくなるほど著しく減少する，一方，よろい綿 中のトラッシュ量は図からわかるように歯角度を変化さ せてあほとんど変らない.しかしフラットの針角度が大 きくなるほど減少する。

D. フラットに付着する全䋐維量

図8 (a) (ドッフ>回転数 $30 \mathrm{rpm}$ の場合), 図 8(b) （真の緎維移行率56\%の場合）にフラットに付着する全

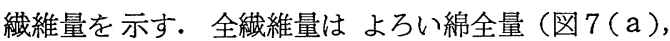

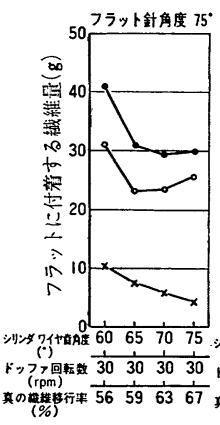

図 8 (a) フラットの 全織維量 (ドッファ回転数 $30 \mathrm{rpm}$ )

図 7(b)) とフラット活動綿量 (図 4(a), 図 4(b)) の合計量であり,フラットの負荷を示すあのである. 図 8 (a)の全繊維量は シリンダ ワイヤの歯角度を $75^{\circ}$ か ら $65^{\circ}$ まで小さくしてもほとんど変らないが $60^{\circ}$ で著し く増加する.また図8（a）に拝いて，上ろい綿全量は〉 ラット活動綿量の $3 \sim 5$ 倍あり, 全繊維量の大部分を占 めている.

図8 (b)-1の全瀻維量はシリンダワイヤの歯角度 を变化させてす図8 (a) と同じ傾向を示す.しかし歯角 度 $75^{\circ}$ から $65^{\circ}$ までの全繊維量は図 8 (a)のそれよりや や多い. 図 $8(\mathrm{~b})-2$ の 全繊維量は歯角度を $75^{\circ}$ 加 $65^{\circ}$ まで小さくしてあほとんど変らないが $60^{\circ}$ でやや多 くなる. 図8 8 (b) - 3 の全瀻維量は歯角度を变化させて
あほとんど変らない．また全緘維量はフラットの針角度 が大きくなるほど著しく減少する.

目8(a), 図8(b)の結果より, シリンダワイヤの 歯角度減少によるシリンダへの緎維の巻付きはシリンダ 活動綿量の増加よりあ（図 4(a)) フラットに付着する 全繊維量の異常な增加（図8(a), 図8(b)-1) が原 因と考えられる，したがって繊維の巻付きを防止するに はフラットの全繊維量が少ない針角度の大きいフラット

（例えば $95^{\circ}$ のフラット）を採用するととも有効な一方 法と考えられる.

\section{3 スライバ}

A. スライバ中の異物数

図 9 (a) (ドッファ回転数 $30 \mathrm{rpm}$ の場合), 図 9(b) （真の織維移行率56\%の場合）にスライバ中の異物個数

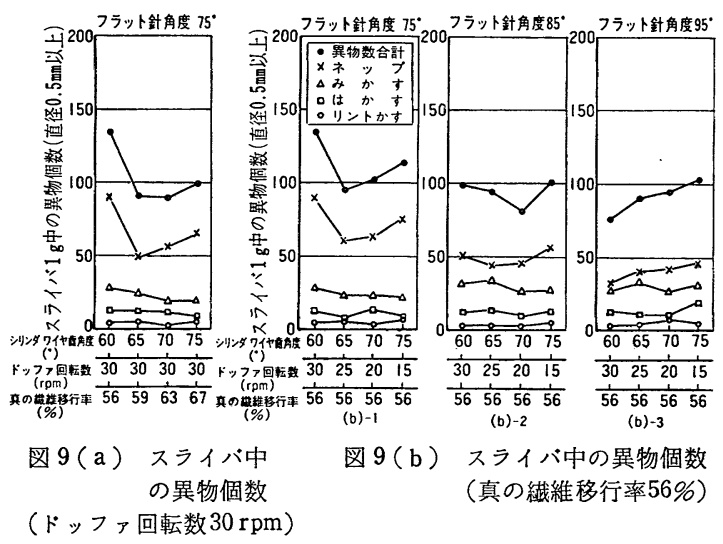

(值条 $0.5 \mathrm{~mm}$ 以上のあの) 以) $^{4}$ 示す. 図 $9(\mathrm{a})$ のネップ 数はシリンダ ワイヤの歯角度が $75^{\circ}$ から $65^{\circ}$ まで小さ くなるほど減少するが，60で著しく増加する，スライ バ中のネップ数はシリンダに付着する繊維量とフラット に付着する縬維量とに相関があると考えられるのでこの 実験で屯シリンダの活動綿量（図4 (a)）フラットの活 動綿量(図 4(a), 図 4(b)), よろい綿全量(図 7(a), 図 7(b)), フラットの全繊維量 (図8 (a), 図8(b)) 等をそれぞれ測定した。その結果，4つの繊維量のうち よろい綿全量がネップ数と最む相関があった．したがっ てネップ数がシリンダ ワイヤの歯角度の変化に対し図 9（a）のような傾向を示した理由としては次のように考 えられる. シリンダ ワイヤが繊維を把持する力は歯角 度が小さくなるほど増加するので よろい綿全量は図 7 (a) のようにシリンダ ワイヤの歯角度が $75^{\circ}$ から $65^{\circ}$ までは隇少したが $60^{\circ}$ では著しく増加した．そのためこ れらのよろい綿全量の 挙動が ネップ数に影響を与えた あのと考えられる.

一方，図9(a)の みかす数は歯角度が小さくなるほ どやや增加するが，はかす数，リントかす数等は歯角度 
を変化させてあほとんど変らない。

図 9(b)-1 のネップ数は歯角度を変化させてあ図 9 (a) 之同じ傾向を示す. しかし歯角度 $75^{\circ}$ から $65^{\circ}$ まで のネップ数は図9(a)のそれよりやや多い. また図 9 (b) - 2, (b)-3のネップ数は歯角度が小さくなるほ ど減少する. これはワイヤ歯角度の減少が把持力を増加 させよろい綿全量を減少させたためと考えられる(図 7 (b) -2 ，（b ）－3）. またネップ数はフラットの針角 度が大きくなるほど減する，したがってネップ数はシリ ンダ歯角度 $60^{\circ}$, フラット針角度 $95^{\circ}$ の場合が最小とな る.

一方, 図 9(b)の みかす数, はかす数打よびリント かす数等はシリンダ ワイヤの歯角度を変化させてもほ とんど変らない。 しかし みかす数はフラットの針角度 が大きくなるほどやや増加する。

B. スライバの織維長

図10(a) (ドッフっ回転数 $30 \mathrm{rpm}$ の場合), 図10(b)

(真の緘維移行率56\%の場合) にスライバの平均繊維長

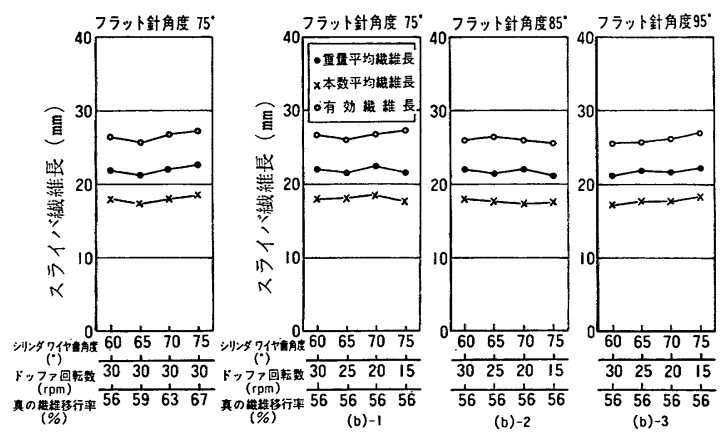

図10(a) スライバ繊維長

(ドッファ回転数 $30 \mathrm{rpm}$ )

図10(b) スライバ繊維長 （真の繊維移行率 $56 \%$ )

ならびに有効瀻維長を示す. 図10(a), 図10(b) とむに 本数平均瀻維長, 重量平均瀻維長ならびに有効織維長は シリンダ ワイヤの歯角度を変化させてあほとんど変ら ない.

図11(a) (ドッファ回転数 $30 \mathrm{rpm}$ の場合), 図11(b) (真の織維移行率 $56 \%$ の場合) にステープル ダイヤグラ ムから求めたスライバの織維長別累積重量割合を示す. 図11(a), 図11(b)とむに重量割合は シリンダ ワイヤ の歯角度を変化させてもほとんど変らない。

\section{6. まとめ}

針角度 $40^{\circ}$ の針布ドッフっを付けたカード機で, シリ ンダ ワイヤの歯角度を $75^{\circ}$ から $60^{\circ}$ まで変化させて実 験した. シリンダ ワイヤの歯密度は $356 /(25.4 \mathrm{~mm})^{2}$ とした. ての場合, ドッフっ回転数を $30 \mathrm{rpm}$ にした実 験 $(A)$ と真の瀻維移行率を $56 \%$ にした実験 $(B) の 2$ 通り
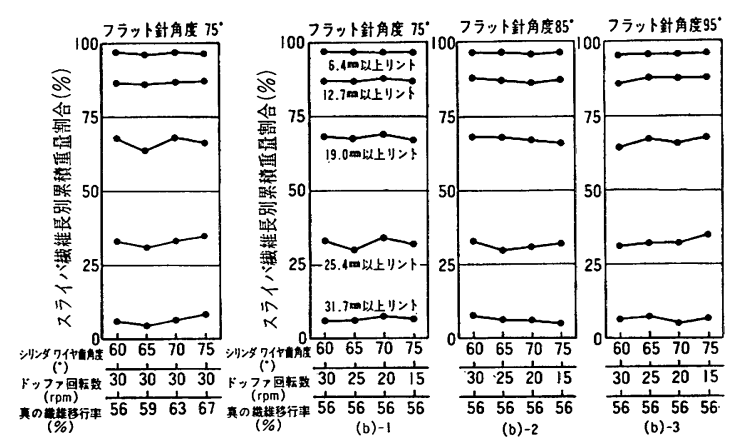

図11(a) スライバ繊維 長重量割合

(ドッファ回転数 $30 \mathrm{rpm}$ )

四11(b) スライバ瀻維長重 量割合

（真の䌜維移行率56\%）

の実験を行った。また実験(B)、ではフラットの針角度 を $75^{\circ}$ から $95^{\circ}$ まで変化させてフラットの針角度の影響 あ調べた・実験結果を要約すると次のようである.

1) 実験(A)の シリンダ活動綿量はシリンダワイヤ の歯角度が小さくなるほどわずかに增加する．その量や 増加率はフラット活動綿量に比べはるかに小さい.

2) フラット針角度 $75^{\circ}$ で実験 $(A)$ と実験 $(B)$ とを比 較すると, フラット活動綿量, よろい綿全量, スライバ 中のネップ数およびスライバの繊維長等はシリンダワ イヤの歯角度の変化に対しまったく同じ傾向を示す。

3）実験(B)のフラット活動綿量はシリンダ ワイヤ の歯角度が小さくなるほど著しく增加する.

4) 実験(B)のよろい綿全量はシリンダワイヤの歯 角度が小さくなるほど減少する.しかしフラット針角度 $75^{\circ}$ の場合のみは歯角度 $60^{\circ}$ で著しく増加する.

5） 実験(B)のスライバ中のネップ数はシリンダ ワ イヤの歯角度が $75^{\circ}$ から $65^{\circ}$ まで小さくなるほど減少す る. しかし $60^{\circ}$ になると $65^{\circ}$ に比べフラットの針角度が $75^{\circ}$ では著しく増加するが $95^{\circ}$ ではさらに減少する．ま たネップ数はフラットの針角度が大きくなるほど隇少す る.

6) 実験(B)のスライバ中の みかす数，はかす数, リントかす数等は シリンダ ワイヤの歯角度を変化させ てあほとんど変らない。しかし みかす数はフラットの 針角度が大きくなるほどやや増加する。

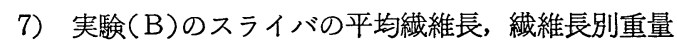
割合等はシリンダ ワイヤの歯角度を変化させてもほと んど変らない。

以上の結果より, シリンダ ワイヤは従来の $75^{\circ}$ の歯 角度より $65^{\circ}$ の歯角度の方がスライバ中のネップ数を減 少させるのに有効であるととがわかった。しかむフラッ トの針角度を $95^{\circ}$ にすれば歯角度を $60^{\circ}$ にしてあネップ 数は $65^{\circ}$ よりさらに減少するてとがわかった。

これらの結果はメタリックワイヤを巻いたドッファ 
を使用してあドッフっの䌜維移行率が同じであれば同一 の結果が得られるはずである.

(付記) 本研究では名古屋工業大学学生山形勘司君の協 力を得た.
文 献

1) 野㟢長二, 峰尾良知, 安藤国輔, 木村 弘; 緘機誌, 10, 621 (1957)

2) 長谷川 進, 木村 弘 : 織機論文集, 21, T 35 (1968)

3) 長谷川 進, 木村 弘; 織機論文集, 22, T 160 (1969)

4) 木村 弘, 長谷川 進; 織機諭文集, 24, T 9 (1971)

5) 上田和男, 大越善彦, 白井憲一; 㵶機誌, 12, 463 (1959)

6）繊維学会編：“緎維物理学” 丸善, (1962), p. 6 